\title{
The Role of Left-Behind-Children Caretaker in Improving Learning Motivation Study in Adipala District, Cilacap Regency, Central Java Indonesia
}

\author{
Dewi Indah Pertiwi \\ Tyas Retno Wulan \\ Hendri Restuadhi \\ Departement of Sociology \\ Faculty of Social and Political Sciences \\ Jenderal Soedirman University \\ Indonesia
}

\begin{abstract}
Adipala is a region in Cilacap, Indonesia, which has significant number of married women who work in abroad, known as Indonesia migrant workers/labors (IML). They flew overseas and left their family (children and husbands) behind. At that point, the family lost their main figure in taking care of the children. This is why these children often known as left-behind-children (LBC). In spite of this, such role usually took over by their husbands (father of the LBC) and or other members of the family (grand mother or aunt). In caring LBC, it is important to pay close attention to their education and by this means lifting up their learning motivation. This research aims at finding out the relation pattern between caretaker and $L B C$, as well as their effort to cope with the role and obstacle in raising up the LBC's learning motivation. This research uses descriptive qualitative method and has in-depth interviewing 29 informants (care taker of LBC). This research conducted in Welahan Wetan, Glempangpasir, and Pedasong, Adipala, Cilacap. The research shows that the caretakers have been caretaking the LBC for more than five years. The majority of the caretakers are the fathers of the LBC themselves whom also had his own job and consequently the bond between them is less intimate and the attempt to raise up the LBC's learning motivation is also less optimum. In order to keep the LBC well motivated, the caretakers give them advise, reward, and punishment.
\end{abstract}

Keywords : Role, Caretakers, Left-Behind-Children, Learning Motivation

\section{A. Introduction}

The limited job opportunities in Indonesia along with increasingly higher cost of economic needs have been the factors which drive IML to have a job overseas (Mulyadi, 2003: 37). In the last few years, the number of IML working abroad is dominated by women, commonly known as Tenaga Kerja Wanita (TKW/Indonesian Women Migrant Labor) and most of them are married (www.bnp2tki.go.id accessed on 4 January 2018). This means that these women left their family - their husbands and children - behind. It is because of this, UNICEF designate these children as Left-Behind-Children (LBC). In a study conducted by PSKK UGM, Sri Purwatiningsih states that children would have prefer their fathers migrate than their mother or both of them (cpps.ugm.ac.id accessed on Monday, 16 April 2018).

The Komisi Perlindungan Anak Indonesia (KPAI/Indonesia Commission for Children Protection) estimates that around 11.2 million LBC lost their parenting right and love from their mothers every year (www.kpai.go.id accessed on 8 January 2018). The parenting of these LBC are then assigned to the father or figures other than the LBC's parents such as grandfather and grandmother (one of them), uncle and aunt, or other relatives. The patriarchical culture in Indonesia which places mother as the main figure in caring to their children makes the leaving of mother causes LBC a certain problem to face their life. They lost the figure whom to accompany and nurture them. It also deteriorate their learning capability and achievement at schools. In Cilacap Regency, 6 of its 24 districts contribute quite significantly in the high number of women IML. Adipala district is one of these six districts. Despite of the fact that Adipala district is not the highest contributors to the number of women IML of Cilacap Regency, the departure of these women IML to have a job overseas inevitably effect on the education of children whom they leave behind at home (Yuniastuti, 2014; Saputro, 2015; Lestari, 2016). This leaves questions, who will look after LBC? Who will responsible to LBC's education? 
Who will taking care of them? Start out from those questions, this research conducted to focus on finding out the role played by the LBC's caretaker in Adipala district in improving their learning motivation. These caretaker figures should develop daily habits and perform the parenting role to the $\mathrm{LBC}$, including improving their learning motivation.This is important since the success and achievement in education will begin with the very existence of learning motivation. A good relationship between the caretaker and LBC is urgently needed to allow the methods used or efforts made by the caretaker in nurturing and educating LBC. In short, this is important particularly in terms of the children's educational development.

\section{B. Method}

This research is conducted in Adipala district, Cilacap Regency, Central Java. The research sites are in three villages: Welahan Wetan, Glempangpasir, and Pedasong. According to Teguh Prastowo, Adipala Head of District Government, most of families in those three villages have its members who work overseas as IML. This is the main information about IML in such district since their are no available formal data.

The subject of this research are those who are taking care of LBC and they are father, aunt, and grand mother. They taking care LBC who are 5th to 12th grade of public/vocational secondary schools. These care taker are assigned to nurture and care for LBC since the mother working overseas as IML. Table below shows the characteristics of this research subjects.

Table 1. Main Characteristics of Research Subject

\begin{tabular}{|c|c|c|c|c|c|c|}
\hline $\begin{array}{c}\text { Caretaker's } \\
\text { (Initial) name* }\end{array}$ & Sex & Last Education & $\begin{array}{c}\text { Age } \\
\text { (years } \\
\text { old) }\end{array}$ & $\begin{array}{l}\text { Relationship } \\
\text { with LBC }\end{array}$ & Address & Occupation \\
\hline Yuda & $\bar{M}$ & Junior High & 38 & Father & Welahan Wetan & Business \\
\hline Soka & M & Elementary & 50 & Father & Welahan Wetan & Farmer \\
\hline Anto & M & Junior High & 40 & Father & Glempangpasir & Labor \\
\hline Wahyu & M & Elementary & 46 & Father & Glempangpasir & - \\
\hline Simi & $\mathrm{F}$ & Elementary & 38 & Aunt & Glempangpasir & Business \\
\hline Sugiri & M & Junior High & 41 & Father & Glempangpasir & Tailor \\
\hline Sumoko & M & Junior High & 41 & Father & Glempangpasir & Craftsman \\
\hline Jadi & M & Elementary & 42 & Father & Glempangpasir & Farming labor \\
\hline Nina & $\mathrm{F}$ & Failed Elementary & 60 & Grandmother & Glempangpasir & Farmer \\
\hline Sik & M & Failed Elementary & 55 & Father & Pedasong & Farming labor \\
\hline Tomas & M & Elementary & 35 & Father & Pedasong & Farmer \\
\hline
\end{tabular}

*Names are changed for ethical purpose

In this research, data is collected in in-depth interview. The interviews conducted from February 21th to March 6th 2018 at the research subjects homes. Most interviews are conducted in Javanese "krama" (high) language. Only a small portion of the interviews done in Bahasa Indonesia, Indonesia natoinal/official language. All interviews guided with interview guidelines to ensure valid data. However, as the conversation goes, the researchers let it be as natural as possible, as long as it relates to the research topic.

The technique for analyzing the data is interactive data analyses (Miles and Huberman, 1992: 15-21) or also known as ongoing analyses (Taylor \& Bogdan, 1984: 128). This data analyses consists of three main stages, namely, data display, data reduction, conclusion drawing and verification. These stages conducted interactively and iteratively until the researchers have saturation data. The very first stage is data collection. When the data has been collected, it follows by data display, i.e. composing interviews transcripts. The next stage is reducing the data by preparing the categories of data and information available in the transcript based on the research topic and subtopics. Next is conclusion drawing,i.e. interpreting the previously reduced data. In their application, the researchers can continuously repeat all of these stages until data saturation is achieved.

The researchers have interviewed different subjects to validate data. It conducted to obtain alternative pespectives from different people (Taylor \& Bogdan, 1984:68-70; Miles \& Huberman 1992:434-437). In this research the validation subjects are LBC themselves and their teachers at schools. The table below shows the characteristics of validation subjects. 
Table 2. Characteristics of LBC in Welahan Wetan, Glempangpasir and Pedasong Villages

\begin{tabular}{ccccc}
\hline \hline Name* & Sex & Address & Grade & School \\
\hline \hline Afi & $\mathrm{F}$ & Welahan Wetan & 11 & SMK Kroya \\
Ivran & $\mathrm{M}$ & Glempangpasir & 8 & SMP Adipala \\
Ifra & $\mathrm{M}$ & Glempangpasir & 7 & SMP Adipala \\
Winda & $\mathrm{F}$ & Glempangpasir & 7 & SMP Adipala \\
Finda & $\mathrm{F}$ & Glempangpasir & 12 & SMA Binangun \\
Ikha & $\mathrm{F}$ & Glempangpasir & 12 & SMK Kroya \\
Tedi & $\mathrm{M}$ & Glempangpasir & 9 & MTs \\
Faruk & $\mathrm{M}$ & Glempangpasir & 6 & SD Glempangpasir \\
Ravli & $\mathrm{M}$ & Pedasong & 6 & SD Pedasong \\
Wimi & $\mathrm{F}$ & Pedasong & 10 & SMK Kroya \\
\hline \hline
\end{tabular}

*M : Male; F : Female

*Names are changed for ethical purpose

Table 3. Characteristics of (homeroom) teachers at LBC's schools

\begin{tabular}{ccccc}
\hline \hline Name & Sex & Address & Class & School \\
\hline Sopi & M & Mujur & 9 & SMP Binangun \\
Busi & M & Kesugihan & 8 & SMP Adipala \\
Din & F & Glempangpasir & 7 & SMP Adipala \\
Sira & F & Glempang pasir & 7 & SMP Adipala \\
Edi & M & Maos & 12 & SMA Binangun \\
Runi & M & Welahan Wetan & 9 & MTs \\
Mawan & M & Glempangpasir & 6 & SD Glempangpasir \\
Tut & F & Glempangpasir & 6 & SD Pedasong \\
\hline \hline
\end{tabular}

*M : Male; F : Female

*Names are changed for ethical purpose

\section{Research Result}

\section{C.1. Being a Caretaker for Left-Behind-Children}

Upon their mother's departure to work overseas, LBC generally live with and are nurtured by their father or grandparents or even other relatives. Taking several regions (districts) in Cilacap Regency into consideration, it is evident that they have some push factors which drove women to work overseas. However, two main factors are poverty and a scarcity of jobs at home. From the existing 24 districts in Cilacap, Adipala districtis and Kesugihan District recorded to have the highest contribution in women IML deployment to Hong Kong (Official Data on IML according their Destination Country, Cilacap Local Government Report 2016). Nevertheless, the limited data available regarding the number of LBC in Adipala district urged the researchers to get themselves in the field to find out and determine their research subjects which meet the predetermined criteria. Fortunately, in Adipala district, particularly in Welahan Wetan, Glempangpasir and Pedasong villages, it is not hard to find LBC and their care takers. In those three villages, almost all famillies have at least one of their family members working overseas as IML.

The modern industry has provided women with greater opportunities to have economic freedom without leaving their household duties. Woman's main position in all societies is to be a housekeeper and a mother (Goode, 1987: 221). For this reason, to work overseas as IML decides by these women would have need some rational choices: gaining economic prosperity and leave their children or try to live in poverty and nurturing their chlidren. According to rational choice theory by Friedman and Hetcher (Ritzer, 2014: 332-333), there are two main drivers of action, i.e. resource limitation and social institution. The resource limitation can be said as being related with the economic state of LBC's parents and the social institution which has to do with the rules and laws regarding child's rights. The decision of woman - as a wife and also a mother - to work or even as the family's economic backbone (a breadwinner, in gender term) become no longer a taboo in the community. In addition, gender equality on women's mindset seem to play some role in encouraging them to work. 
Nowadays, women would rather chose to work to increase their family's welfare or to merely satisfy their desire (Goode,1987: 153). However, this improvement in women consciousness is hardly to adopt by men.

In Adipala district, particularly in Welahan Wetan, Glempangpasir and Pedasong villages, it apparents that so many children live without the presence of their mothers. In general, they have been left by their mothers since under five years old. According to Anto, he has been nurturing his only son: "Pun kawit umur 2 tahun niku Ivran ditinggal ibune.." (Javanese: Since Ivran was 2 years old, he had been left by his mother...) ${ }^{1}$. According to Javanese culture, as a man (husband and father), Anto is not use to nurture children. As his wife left him to work overseas, Anto has to learn to nurture his son. Those other LBC care taker also face their own problem: raising and nurturing children whom not their own.

\section{C.2. The Relations between Caretakers and Left-Behind-Children}

Mulder (in Endraswara, 2010: 42) suggests that one of the conditions which shows a strong family relation is the closeness between parents and their children. This closeness between parents and their children means the closeness of both the mother and the father to their children, not just one of them. This is because the development of children begins from the closeness relationship between the father and the mother and their children. The father and the mother share the same position: as parents of their children. Wulan et al, (2018) finds that the family division of roles by gender has inevitably formed a separation of works between man and woman. Eventually it affects the parents-children relation. In his family, man is forced to be a figure whom responsibility is to meet family economic needs. This responsibility makes him drove away from his children. Woman, in contrast, has her own responsibilities and nurturing children is her main role. It apparents that woman has closer ties to her children. Hence, in the case of women IML families, when the mother goes overseas for a certain amount of years to work, the effects to her children can be psychologically and sociologically harder. At this point, it is the case of left-behind-children.

In the case of LBC, the relationship between children and their mothers can no longer be built robustly. Despite of today's technological advancement in communication, it can help only a little bit to such relationship. Women IML usually entrust their LBC to their father or other care takers who still have familial relationship. These care takers have to take the role as a mother of LBC. The care takers, who in this case are those individuals who have previously been in a certain structure (as a father, grand mother, and aunt) should enter a new structure and play an additional role of a substitute mother for the LBC. When they become a mother for the LBC, these care takers are of course forced not just to serve a good parenting such as to feed and care for LBC, rather they should also pour them with affection, just like a mother to her biological child. Playing such a role is never easy, particularly for those care takers who are not the parents of the LBC. The table below describes the realtion between care takers and LBC.

Table 4. Relationship between Care takers and LBC

\begin{tabular}{|c|c|c|}
\hline Care taker & Description & Type of Relation \\
\hline Yuda & $\begin{array}{l}\text { The relation between Yuda and his only child, Anr, is normal just like any } \\
\text { other parent and child. There is nothing special from their relationship, yet it } \\
\text { cannot also be said as distant. Anr also occassionally helps his father deliver } \\
\text { the order and collect grasses to feed their goats. }\end{array}$ & "Ordinary (normal). \\
\hline Soka & $\begin{array}{l}\text { The relationship between Soka nd his child, Afi, is normal just like any other } \\
\text { father and his daughter. }\end{array}$ & Ordinary (normal). \\
\hline Anto & $\begin{array}{l}\text { They are fine. This is because Anto can follow the flow of his son's world who } \\
\text { is now a teenager. They interact intimately like peers. Anto's occupation which } \\
\text { allows him to mostly stay at home makes it easier for him to monitor his son, } \\
\text { Ivran. Anto also supports the Taekwondo course that Ivran takes after school. } \\
\text { Anto always presence whenever his son has Taekwondo match. }\end{array}$ & Like peers (intimate). \\
\hline Wahyu & $\begin{array}{l}\text { Most of the time Wahyu stays at home, hence allowing him to build a normal } \\
\text { relationship with Ifra since they are always together. }\end{array}$ & Ordinary (normal). \\
\hline Simi & $\begin{array}{l}\text { Winda thinks Simi as if she is her own mother. This is because Simi can give } \\
\text { her motherly love and nurture her well, as if she is her own daughter. }\end{array}$ & $\begin{array}{l}\text { Like a mother to her own } \\
\text { daughter (LBC thinks the } \\
\text { caretakeras her own } \\
\text { mother). }\end{array}$ \\
\hline
\end{tabular}

\footnotetext{
${ }^{1}$ Interview with Anto on 24 February 2018 at 09.32 AM.
} 
Sugiri The relationship between Sugiri and his daughter, Finda, is relatively very intimate. It can be seen from the absence of gap that could restrain them. Their relationship can even be said like friends.

Sumoko Since he spends most of his time at home, Sumoko can fully observe his only daughter, Ikha. They frequently go out for meals and the communication built between Sumoko and Ikha is highly intimate just like peers.

Jadi The relationship between Jadi and his son, Tedi, is relatively less intimate since Jadi is too quiet and pays less attention to his son and his house hygiene.

Nina Nina is inclined to always give what her grandson, Faruk, wants. She even nearly never scolds Faruk. She is just like any other grandmother who always spoils her grandson.

Sik Since he has to work at the rice field, the relationship between Sik and his son, Ravli, is relatively ordinary. They communicateonly when they need to. This is also a result of Ravli being too occupied with playing games in his mobile phone.

Tomas The relationship between Tomas and his daughter, Wimi, is just like a parent and his child in general. Despite spending much of his time in the rice field,

Like peers (very intimate).

Like peers (very intimate).

Less intimate (not as how it should be).

Ordinary (normal).

Built less well (not as how it should be).

Ordinary (normal). Tomas still manage to pay attention to his daughter.

\section{C.3. Improving Learning Motivation of LBC}

Parents are the first and main figures in a child's education. Parents usually entrusted their children education to schools. However, parents still have some responsibilities to their children learning achievement (Umar, 2015: 25). Parents are the first teachers for their children. They are the first figures whom introduce basic educations for their children. In learning of basic educations, motivation is the ultimate requirement one needs to pay attention to. Therefore, parents ought to encourage their children to study harder in order to increase their learning motivation. Developing learning motivation is the real form of the important role that parents play in their children's education (sahabatnestle.co.id, accessed on 8 May 2018). Parents also ought to develop wilful communication to their children to perform their attention and affection. It has significant influence on their chidren learning motivation. At that point, parents could develop some expectations that their children might stimulate to achieve higher education in the future.

However, it is not easy to improve LBC learning motivation since they have left behind by their main figure motivator: mother. Care takers of LBC usually only be assigned to nurture the LBC but some of them even have gone further and more intimate. When LBC is nurtured by their own father, it is still possible to do the parenting efforts related in improving LBC learning motivation. However, it is not the case when the children are nurtured by figures other than their parents. To be able to improve the LBC's learning motivation, they should first develop a parent-child-like relationship. If the LBC and these caretakers fail to develop an intimate relationship, any effort of nurturing and improving LBC learning motivation will hardly carrying out. Nevertheless, care takers of LBC (fathers, grand mother, and aunt) acknowledge that they have attempted to improve the LBC's learning motivation. In so doing, they have spend a certain amount time in nurturing and improving learning motivation of LBC since they have their own activities such as working, doing their own houseworking, and even nurturing their own children. It leads to the less optimal in nurturing of LBC than they expect it to be.

\section{C.4. Efforts to Improve the Learning Motivation of Left-Behind-Children}

As the care takers of LBC, they are not only to make sure to feed them, handling their needs, and other physical needs. Encourage LBC to learn and improving their learning motivation are also urgently needed. It is important in order to fulfill the LBC's psychological needs as well. The efforts or ways to improve the LBC's learning motivation conducted by most LBC's care takers include verbal advises and instructs them to study harder. Some other care takers also use different ways such as rewarding the LBC with gifts when they can obtain good marks and, in contrast, punishing them when their marks are lower at schools. According to care takers, such ways in improving LBC's learning motivation is fairly effective despite the absence of mother figure in the family. According to Wahyu, father of Ifra, the efforts are:

“...pas waktune belajar, ora nyetel TV, kon belajar disit. Iya paling support kaya kue lah. Seneng. Ngucapna bangga terus ben bocah kue lewih semangat maning gole belajar. "2 (Javanese: when it is time to study, TV

\footnotetext{
${ }^{2}$ Interview with Wahyu on 24 February 2018 at 1:33 PM.
} 
should not be turned on, they have to study first. Yes, that kind of supports. We are happy. I often said to him that I am proud of him and hopefully this can make him more motivated to study).

Wahyu is a care taker and a father at the same time to Ifra. His health condition forces him to stay at home. His wife substitues him to earn a living as IML in overseas. The reason why he does not give Ifra reward and punishment is that it will be a self-taught for Ifra himself to be independent rather than rely on them. Even without reward and punishment, Ifra can achieve relatively good learning achievement. The table below shows the efforts conducted by the care takers in improving learning motivation of LBC.

Table 5. Efforts to Improve LBC's Learning Motivation

\begin{tabular}{|c|c|c|}
\hline Caretakers & Description & Efforts \\
\hline Yuda & Giving advises to make Anr more motivated to study hard. & Verbal advise. \\
\hline Soka & $\begin{array}{l}\text { Giving advises to make Afi more motivated to study hard and reward } \\
\text { him for obtaining good marks. }\end{array}$ & Verbal advise and reward. \\
\hline Anto & Giving advises to make Ivran more motivated to study hard. & Verbal advise. \\
\hline Wahyu & $\begin{array}{l}\text { Giving advises and continually congratulating Ifra for obtaining } \\
\text { good marks at school. }\end{array}$ & Verbal advise and reward. \\
\hline Simi & $\begin{array}{l}\text { Giving advises and rewarding Widi for obtaining good scores at } \\
\text { school. }\end{array}$ & Verbal advise and reward. \\
\hline Sugiri & $\begin{array}{l}\text { Giving advises and rewarding Finda for obtaining good scores at } \\
\text { school. }\end{array}$ & Verbal adviseand reward. \\
\hline Sumoko & Giving advises to make Ikha more motivated to study. & Verbal advise. \\
\hline Jadi & $\begin{array}{l}\text { Giving school's supporting facilities (notebook) to make Tedi more } \\
\text { motivated to study. }\end{array}$ & Reward. \\
\hline Nina & Rewarding Faruk to make him more motivated to study. & Reward. \\
\hline Sik & Giving advises to make Ravli more motivated to study hard. & Verbal advise. \\
\hline Tomas & Giving advises to make Wimi more motivated to study hard. & Verbal advise. \\
\hline
\end{tabular}

Source: Interview between February 21th -March 6th 2018

\section{C.5. Obstacles in Improving Children-Left-Behind's Learning Motivation}

Care takers has to face some obstacles in nurturing LBC and in improving LBC's learning motivation. Most of LBC has grown up accustomed to live without the presence of their mothers. It is understandably hard to deal with LBC under this circumstance. In addition to the necessity for care takers to develop an intimate relationship, they should also be able to manage their roles in many other structures such as, the position in his/her own household, at his/her own work, in the society, as LBC's care taker, and so forth. Sik attempts to improve Ravli's learning motivation is surely directed to make Ravli a smart and high-achieving child at school. However, Sik's effort is disrupted by Ravli's activity in playing game on his mobile phone. Giving Ravli a mobile phone so that he can connect to his mother has raise unlikely the new problem: Ravli reluctant to study. In short, the obstacles encountered by LBC's care takers in improving LBC'slearning motivation are shown in table below.

Table 6. Obstacles in Improving LBC's Learning Motivation

\begin{tabular}{|c|c|c|}
\hline Caretaker & Description & Obstacles \\
\hline Yadi & Anr would rather watch TV and play football with friends than studying. & "Watching TV and playing. \\
\hline Soka & $\begin{array}{l}\text { Soka has no knowledge of Afi's courses, hence he cannot follow and guide } \\
\text { Afi's study at home. In addition, Afi would rather watch TV and play her } \\
\text { mobile phone when she is at home. }\end{array}$ & $\begin{array}{l}\text { Has no knowledge on today's } \\
\text { school courses; watching TV } \\
\text { and using mobile phone. }\end{array}$ \\
\hline Anto & $\begin{array}{l}\text { Having too many outdoor activities makes Ivran would rather sleep when } \\
\text { he is asked to study. }\end{array}$ & $\begin{array}{l}\text { LBC have too many outdoor } \\
\text { activities. }\end{array}$ \\
\hline Wahyu & $\begin{array}{l}\text { Wahyu has no knowledge of Ifra's courses, hence he cannot follow and } \\
\text { guide Ifra's study at home. }\end{array}$ & $\begin{array}{l}\text { Has no knowledge on today's } \\
\text { school courses. }\end{array}$ \\
\hline Simi & $\begin{array}{l}\text { The different courses of today's school and the one in the past prevent } \\
\text { Simi from being involved directly in Winda's study at home. }\end{array}$ & $\begin{array}{l}\text { Has no knowledge on today's } \\
\text { school courses. }\end{array}$ \\
\hline Sugiri & Finda keeps on playing her mobile phone. & Use of mobile phone. \\
\hline Sumoko & $\begin{array}{l}\text { Sumoko cannot direct his daughter, Ikha. This is because Sumoko thinks } \\
\text { Ikha is smarter than him. }\end{array}$ & $\begin{array}{l}\text { LBC conceives as more } \\
\text { inteligent. }\end{array}$ \\
\hline Jadi & $\begin{array}{l}\text { Jadi cannot teach Tedi to study at home because the courses in the past and } \\
\text { today have been different. }\end{array}$ & $\begin{array}{l}\text { Has no knowledge on today's } \\
\text { school courses. }\end{array}$ \\
\hline
\end{tabular}


Nina In the evening, Faruk would rather play his mobile phone and watch TV than studying.

Sik At home, Ravli spends more time to play games in his mobile phone.

Tomas Tomas finds that there are no difficulties in improving Wimi's learning motivation.
Use of mobile phone and watching TV.

Use of mobile phone.

No obstacle.

Source: interviews between February 21th - March 6th 2018

\section{C.6. Way of Dealing with the Obstacles in Improving Learning Motivation of Left-Behind-Children}

When the efforts conducted by care takers in improving LBC's learning motivation is facing obstacles, he/she will keep on thinking of how to deal with them. Through this thinking process, new actions then appear as solutions to cope with the obstacles. Most care takers dealing with the obstacles by rewarding and punishing the LBC. This way, LBC will study harder. The table below shows the way in which care takers deal with the obstacles inhibiting in improving LBC's learning motivation.

Table 7. Ways of Dealing with Obstacles in the Effort of Improving LBC's Learning Motivation

\begin{tabular}{|c|c|c|}
\hline Caretaker & Description & $\begin{array}{l}\text { Ways to Deal with } \\
\text { Obstacles } \\
\end{array}$ \\
\hline Yadi & Take hold of the motorcycle and lowering the pocket money temporarily. & Punishment. \\
\hline Soka & $\begin{array}{l}\text { Not repairing damaged mobile phone and no pocket money will be given to pay the } \\
\text { internet bill. }\end{array}$ & Punishment. \\
\hline Anto & $\begin{array}{l}\text { Giving advises to prevent the child from having limited education as his parents } \\
\text { did. }\end{array}$ & Verbal advise. \\
\hline Wahyu & Asking the child to study in groups with his friends. & Verbal advise. \\
\hline Simi & Having the child attend private tutoring with one of teachers in their neighborhood. & $\begin{array}{l}\text { Having the child } \\
\text { attend private } \\
\text { tutoring. }\end{array}$ \\
\hline Sugiri & $\begin{array}{l}\text { The mobile phone is seized temporarily or ceasing the money supposedly to pay the } \\
\text { internet bill. }\end{array}$ & Punishment. \\
\hline Sumoko & Merely asking Ikha to study harder. & Verbal advise. \\
\hline Jadi & Asking Tedi to study in groups with his friends. & Verbal advise. \\
\hline Nina & $\begin{array}{l}\text { Telling Faruk's mother if he is reluctant to study, seizing the mobile phone, and } \\
\text { giving no money to pay the internet bill. }\end{array}$ & Punishment. \\
\hline Sik & No intervention is made for he fears of the child's rebellion & $\begin{array}{l}\text { Giving no } \\
\text { intervention. }\end{array}$ \\
\hline Tomas & Continuously giving advises to the child to study passionately. & Verbal advise. \\
\hline
\end{tabular}

Source: Result of interviewon 21 February - 6 March 2018

\section{Conclusions}

Based on the findings, below is the conclusions on this research.

1. There have been a good relationship develop between the care takers and LBC. Their relationship is tightly related to the nurturing efforts made, particularly the roles in improving LBC's learning motivation.

2.Nurturing the LBC usually done by their fathers, grandmother and other relatives who are generally female. When the LBC are nurtured by a figure other than their parents, the LBC's parents tend to give the authority to grandmother and aunt. These women are believed to be capable of handling children.

3.In nurturing the LBC, sometimes care takers conducted it less optimally since they have had their own structures (for example: structures in the caretaker's family, in the society, at work and so forth) and activities.

4. When the care takers are fathers, they tend to pay less attention to LBC's education at school. These LBC's fathers do not force their children to be a high-achiever at school. This may be because they focus more on earn a living. In addition, the efforts conducted to improve LBC's learning motivation includes giving verbal advises, reward, and punishment.

\section{E. References}

CPPS UGM. 2016. "MIGRASI: 35 Persen Anak Merasa Berat Saat Ibunya Harus Bekerja ke Luar Negeri”. https://cpps.ugm.ac.id/migrasi-35-persen-anak-merasa-berat-saat-ibunya-harus-bekerja-ke-luar-negeri/, diakses pada Senin, 16 April 2018 
Bahri, Syaiful.2004. Pola Komunikasi Orang Tua dan Anak dalam Keluarga. Jakarta: Rineka Cipta

BNP2TKI.http://www.bnp2tki.go.id/uploads/data/data_12-12-2017_090653Laporan_PengolahanData BNP2TKI _2017_(s.d_November_).pdf. Diakses pada 4 Januari 2018

Bungin, Burhan. 2001. Metode Penelitian Kualitatif. Jakarta: Rajawali Pers

Data Perkembangan Tenaga Kerja Indonesia (TKI) Dirinci Menurut Negara Tujuan Per Kecamatan Di Wilayah Kabupaten Cilacap Tahun 2016. Disnakerin Cilacap

Endraswara, S. 2010. Etika Hidup Orang Jawa: Pedoman Beretika dalam Menjalani Kehidupan Sehari-hari. Yogyakarta: Penerbit Narasi

Goode, William J.. 1987. Sosiologi Keluarga. Jakarta: PT Bina Aksara

Gunarsa, Singgih D. dan Yulia Singgih D. Gunarsa. 2003. Dasar dan Teori Perkembangan Anak. Jakarta: Gunung Mulia

Kinseng, Rilus A. 2017. Strukturgensi: Sebuah Teori Tindakan. Sodality: Jurnal Sosiologi Pedesaan. Diakses pada Senin, 7 Mei 2018

Lestari, Tri. 2016. Aspirasi Pendidikan Dalam Keluarga TKI di Desa Jangkaran Kecamatan Temon Kabupaten Kulon Progo. Skripsi. Universitas Negeri Yogyakarta

Miles, Mathew B. \& Huberman, A, Michael, 1992. Analisis Data Kualitatif, Buku Sumber tentang MetodeMetode Baru. Diterjemahkan oleh Tjetjep Rohendi Rohidi. Jakarta: UI Press

Mulyadi. 2003. “Ekonomi Sumber Daya Manusia- Dalam Perspektif Pembangunan”. Jakarta: Rajagrafindo Persada

Narsidah, Tyas Retno Wulan, Eri W, Rr. Setyawati, Mahmudah. 2014. Buku Pedoman Pengasuhan Anak BMI/TKI Berbasis Komunitas. Banyumas: Paguyuban Peduli Buruh Migran dan Perempuan "SERUNI"

Nashir, Haedar. 2012. "Memahami Strukturasi Dalam Perspektif Sosiologi Giddens", Sosiologi Reflektif Volume 7, Nomor 1, Oktober 2012.

www.e-jurnal.com/2015/01/memahami-strukturasi-dalam-perspektif.html?m=1. Diakses pada Rabu, 7 Februari 2018

Puspitawati, Herien dan Shely Septiana Setioningsih. 2011. "Fungsi Pengasuhan dan Interaksi Dalam Keluarga Terhadap Kualitas Perkawinan dan Kondisi Anak Pada Keluarga Tenaga Kerja Wanita (TKW)”, Jurnal Ilmu Keluarga dan Konsumen, Vol. 4, No. 1, Januari 2015.

http://resipatory.ipb.ac.id/handle/23456789/64508 diakses pada Senin, 8 Januari 2018

Rakhmawati, Istiana. 2015. "Peran Keluarga Dalam Pengasuhan Anak", Jurnal Bimbingan Konseling Islam, Vol. 6, No. 1, Juni 2015, hlm.7. http://download.portalgaruda.org/ diakses pada Senin, 8 Januari 2018

Ritzer, George. 2011. Teori Sosiologi Modern. Edisi Keenam. Jakarta: Kencana

Saputro, Riyayan Dwi. 2015. Pendidikan Karakter Anak Pada Keluarga TKW (Studi Kasus di Desa Nglandung Kecamatan Geger Kabupaten Madiun). Skripsi. IKIP PGRI Madiun

Setyawan, Davit. 2016. "KPAI:Hentikan Pengiriman TKI yang Punya Balita”.www.kpai.go.id/berita/kpaihentikan-pengiriman-tki-yang-punya-balita/ diakses pada Senin, 8 Januari 2018

Subianto, Anwar. 2006. "Pengaruh Pemanfaatan Remitan Buruh Migran Terhadap Pertumbuhan Ekonomi Di Kabupaten Cilacap. Tesis. Universitas Diponegoro, Semarang

Sugiyono. 2008. Metode Penelitian Kuantitatif Kualitatif dan R\&D. Bandung: Alfabeta

Taylor, Steven J. \& Bogdan, Robert. 1984. Introduction to Qualitative Research Methods, a Search for Meanings. New York, USA: John Wiley \& Sons

Umar, Munirwan. 2015. Peranan Orang Tua Dalam Peningkatan Prestasi Anak. Jurnal Ilmiah Edukasi Vol 1, Nomor 1, Juni 2015. Diakses pada Senin, 7 Mei 2018

Yuniastuti. 2014. Kehidupan Sosial Ekonomi TKI dan TKW Serta Dampak Sosial Psikologis Pendidikan Anak, Skripsi. Universitas Negeri Malang

Winkel, W.S. 1996. Psikologi Pendidikan dan Evaluasi. Jakarta: Gramedia

Wulan, T. R., Dalhar, S., Sri, W., Dyah W. D. L., Ariadne T. H., Eri W., \& Hendri R. 2018. Ayah Tangguh, Keluarga Utuh: Pola Asuh Ayah Pada Keluarga Buruh Migran Perempuan di Kabupaten Banyumas, Jurnal Ilmu Keluarga \& Konsumen, Mei 2018, p : 84-95 Vol. 11, No.2,

DOI: http://dx.doi.org/10.24156/jikk.2018.11.2.84 